\title{
Epipelic diatoms in the estuaries of South Africa
}

\author{
GC Bate*, PA Smailes and JB Adams \\ Department of Botany, Nelson Mandela Metropolitan University, PO Box 77000, Port Elizabeth 6031, South Africa
}

\begin{abstract}
Epipelic diatom flora was sampled around the South African coast between the Olifants Estuary, on the cool Atlantic Ocean northwest coast, and the St. Lucia Estuary, on the Indian Ocean northeast coast. Altogether, 333 taxa were identified with 14 being ubiquitous, as they were found in the cool temperate, warm temperate, and subtropical areas, as well as in St. Lucia Estuary situated close to Moçambique. There was little difference between the epipelic diatom species present in intertidal and subtidal areas and, because many of the species have a high tolerance to salinity, with some being found in conditions ranging from freshwater to a salinity of more than $150 \mathrm{psu}$, it was concluded that many of the species sampled do not appear to be reliable indicators for assessing salinity in South African estuaries. Although there was a wide spread of diatoms across all of the estuaries around the coast, the greatest species similarity occurred between the Olifants, Great Berg and Breede estuaries, suggesting that the Breede Estuary, normally considered to fall within the warm temperate region, may be more similar to the cool temperate type estuaries. Data also showed that there was very little similarity between the diatom flora in the rivers flowing into estuaries and the diatom flora in the estuaries.
\end{abstract}

Keywords: diatoms, distribution, estuary, epipelon, salinity, temperature, tidal

\section{Introduction}

There have been many studies on the diatom flora of South Africa. Beginning in the 1960s, much of this was largely taxonomic (Giffen, 1963, 1966, 1970; Cholnoky, 1955, 1963, 1965, 1968 and numerous references therein; Schoeman and Archibald, 1976; Archibald, 1983). More recently, diatom studies have become increasingly focused on ecological interpretations, i.e., in rivers (De la Rey et al., 2004; Taylor et al., 2005; Taylor et al., 2007), in the surf-zone around the coast (Sloff et al., 1984; Campbell and Bate, 1987; Campbell and Bate, 1988a,b; Campbell et al., 1988; Talbot and Bate, 1986; Talbot and Bate, 1987; Talbot and Bate, 1988a,b,c,d; Talbot et al., 1989), a single attempt to examine diatoms in relation to water quality in estuaries (Minne, 2003), and a study of a World Heritage Site (Bate et al., 2008).

Harrison et al. (2000) estimated that there were approximately 370 river outlets to the sea around the South African coastline. Of these, 259 are made up of permanently open (POE) and temporarily open/closed (TOCE) estuaries (Turpie, 2004), estuarine bays, river mouths and estuarine lakes (Whitfield, 1992). However, there have been no studies undertaken in a systematic manner that have reported on the distribution of diatoms present in all of the estuary types around the coast, across salinity gradients and in both intertidal and subtidal domains, i.e., there has been no attempt to identify the distribution of diatom flora in estuaries and to relate this to environmental and geographical variables.

The National Water Act (No. 36 of 1998) makes provision for securing the water resources of the country. This Act, inter alia, requires that not only river resources be protected, but also estuarine resources. An interpretation with respect to estuaries is that sufficient freshwater must be discharged into estuaries in order to protect them to a level approved in terms

\footnotetext{
* To whom all correspondence should be addressed.

푱 + 2782562 5838; e-mail: Guy.Bate@nmmu.ac.za

Received 18 January 2012; accepted in revised form 12 November 2012.
}

of the Resource Directed Measures (RDM) programme of the Department of Water Affairs (DWA), which includes salinity that should normally fall within reasonable limits, i.e. 0-35 psu, except during periods of drought, when higher values might be expected, or during floods, when lower values might be expected.

The quality of estuary water in South Africa, unlike river water, is not presently analysed on a routine basis by any authority; yet the supply of freshwater, in terms of the Act, must be adequate such that estuary water should conform to prescribed quality minima. In areas where agricultural, industrial and municipal effluents reach estuaries, water quality might necessarily include high concentrations of mineral, heavy metal and biological substances. However, because estuaries, and especially permanently open estuaries, receive water from both the river and the sea on a daily basis, one of the major factors that needs to be kept within prescribed limits is salinity. POEs usually display a salinity gradient, being fresher inland and in the upper reaches, without exhibiting a halocline (Van Niekerk, 2007; Snow and Taljaard, 2007). However, this can break down when water is taken from rivers and utilised inland. TOCEs do not always have a salinity gradient because, being closed for variable periods during the year, they may be mixed by wind or, if the freshwater supply continues at a low flow during mouth closure, there may be a relatively fresh area near the head and a saline area, even hypersaline, near the mouth. Hence, POEs are more predictable with regard to the longitudinal salinity profile than are TOCEs (Snow and Taljaard, 2007).

Diatoms are known to respond to salinity and most references describe them as either freshwater, brackish or marine species (Round et al., 1990; Sims, 1996; Gell, 1997; Potter et al., 2006), hence the possibility of using diatoms to integrate and record salinity fluctuations formed part of the purpose of this research. In past South African studies on estuarine microalgal biomass, diatoms were always found to be present, and often make up a large portion of the microalgal community at the base of the estuarine food-chain (Snow, 2000; Snow et al., 
2000; Kotsedi et al., 2012). Hence knowledge of diatom ecology is as vital a part of estuarine management as, for example, the knowledge of grasses is in grassland management.

The realisation that benthic diatoms can, at times, be the most productive organisms at the base of the food chain in aquatic systems, identified the need to extend a previous river investigation (Bate et al., 2002) into estuaries (Bate et al., 2004). At the same time, because diatoms are believed to fall into salinity tolerance categories, among the aims of the estuarine component of this study was to determine: (a) which diatoms were to be found in South African estuaries and (b) whether these might fall into groups that might be used to identify the salinity characteristics of the estuaries. The purpose of being able to identify salinity zones relates to the implementation of the National Water Act, whereby managers of rivers and estuaries are required to protect the freshwater flow into estuaries in order to maintain the ecology in a prescribed management class, which includes salinity. Salinity is an important indicator that can be used to measure changes in freshwater inflow; being able to identify diatoms as indicators of changes in salinity and possibly mineral nutrients would add considerably to the armoury of investigators concerned with microalgae.

Harrison et al. (2000) classified the estuaries of South Africa on the basis of their geomorphology. They identified 6 basic types subdivided into 'normally open' and 'normally closed'. They recognised 2 types of normallyclosed estuaries, viz., those perched above mean sea level and those whose water level was approximately at sea level. The normallyclosed systems were further subdivided into 3 types based on their water surface area, i.e., Type A - small ( $<2$ ha), Type B - medium (2-150 ha) and Type $\mathrm{C}-$ large ( $>150$ ha). The normally-open group were also sub-divided, firstly into two, i.e., non-barred - Type D, and barred. The barred types were further subdivided into two other sub-groups based on the volume of the annual runoff from the land, viz., a mean annual run-off $<15 \times 10^{6} \mathrm{~m}^{3}-$ Type E, and those with a mean annual runoff $>15 \times 10^{6} \mathrm{~m}^{3}-$ Type F. This classification system has been applied to the estuaries sampled in this diatom study.

This estuary study included a selection of estuaries extending along the coast from northern KwaZulu-Natal (Nhlabane and Mhlathuze), southwards along the Cape east coast, south coast and west coast as far north as the Olifants Estuary. Most of the systems included in this study are classified into Type F because they are the larger systems and therefore more important water sources in areas that have been developed. Three systems (Tsitsikamma, Seekoei and Zinkwazi) are classified as Type B. The Tsitsikamma and Seekoei estuaries are warm temperate systems while the Zinkwazi Estuary falls into the subtropical zone. Previous data collected (Bate and Smailes, 2008) on the St. Lucia Estuary are included where relevant. Hence, while there are many other rivers, river sites and estuaries that
Table 1 (he mouth, the water salinity (psu) at the mouth and head oastline because each longitude line cuts the coastline in one position only. (H-type is the estuary type classification according to Harrison et al. (2000), while the eWQI water quality index reported for South African estuaries by these authors: 3 = very poor quality; 3-5 = poor; 5-7 fair; 7-9 = good; >9 very good quality. nd $=$ not reported by Harrison et al. (2000)).

\begin{tabular}{|c|c|c|c|c|c|c|c|}
\hline Estuary & $\begin{array}{l}\text { Date } \\
\text { sampled }\end{array}$ & $\begin{array}{l}\text { Longi- } \\
\text { tude } \\
\text { (E) }\end{array}$ & $\begin{array}{c}\text { Salinity } \\
\text { (psu) } \\
\text { (mouth) }\end{array}$ & $\begin{array}{c}\text { Salinity } \\
\text { (psu) } \\
\text { (head) }\end{array}$ & $\begin{array}{l}\text { Tempe- } \\
\text { rature } \\
\text { region }\end{array}$ & H-type & eWQI \\
\hline Nhlabane & 27/03/1998 & 32.28 & 25 & 0 & WT & nd & nd \\
\hline Mhlathuze & $24 / 06 / 1998$ & 32.05 & 45 & 30 & ST & nd & nd \\
\hline Mtata & \begin{tabular}{|l|}
$28 / 09 / 1999$ \\
\end{tabular} & 29.18 & 35 & 18 & WT & $\mathrm{F}$ & 4.4 \\
\hline Breede 1 & $18 / 03 / 2000$ & 20.85 & 30 & 0 & $\mathrm{CT}$ & $\mathrm{F}$ & 7.5 \\
\hline Knysna & $02 / 05 / 2000$ & 23.06 & 37 & 28 & WT & $\mathrm{F}$ & 8.4 \\
\hline Keurbooms & $03 / 05 / 2000$ & 23.38 & 31 & 2 & WT & $\mathrm{F}$ & 8.0 \\
\hline Goukamma & $05 / 05 / 2000$ & 22.95 & 25 & 10 & WT & $\mathrm{F}$ & 7.4 \\
\hline Great Brak & $05 / 05 / 2000$ & 22.24 & 35 & 25 & WT & $\mathrm{F}$ & 7.7 \\
\hline Breede 2 & $11 / 08 / 2000$ & 20.85 & 7 & 0 & $\mathrm{CT}$ & $\mathrm{F}$ & 7.5 \\
\hline Sundays & $17 / 10 / 2000$ & 25.83 & 24 & 2 & WT & $\mathrm{F}$ & 7.0 \\
\hline Mngazi & $27 / 01 / 2001$ & 29.46 & 30 & 2 & ST & $\mathrm{F}$ & 7.0 \\
\hline Mngazana & $27 / 01 / 2001$ & 29.42 & 35 & 23 & ST & $\mathrm{F}$ & 6.4 \\
\hline Breede 3 & 03/04/2001 & 20.85 & 28 & 1 & $\mathrm{CT}$ & $\mathrm{F}$ & 7.5 \\
\hline Olifants 1 & $21 / 06 / 2001$ & 18.20 & 25 & 1 & $\mathrm{CT}$ & $\mathrm{F}$ & 6.6 \\
\hline Swartkops & $27 / 08 / 2001$ & 25.63 & 38 & 27 & WT & $\mathrm{F}$ & 8.0 \\
\hline Bushmans & $28 / 08 / 2001$ & 26.64 & 34 & 32 & WT & $\mathrm{F}$ & 8.0 \\
\hline Kowie & $29 / 08 / 2001$ & 26.88 & 35 & 20 & WT & $\mathrm{F}$ & 8.1 \\
\hline Great Fish & $30 / 08 / 2001$ & 27.13 & 33 & 0 & WT & $\mathrm{F}$ & 7.4 \\
\hline Mkomazi & $04 / 03 / 2002$ & 22.93 & 1 & 0 & ST & $\mathrm{F}$ & 7.8 \\
\hline Great Berg 1 & $29 / 01 / 2002$ & 18.15 & 34 & 23 & $\mathrm{CT}$ & $\mathrm{F}$ & 5.1 \\
\hline Gourits & $31 / 01 / 2002$ & 21.89 & 39 & 27 & WT & $\mathrm{F}$ & 7.8 \\
\hline Goukou & $31 / 01 / 2002$ & 21.42 & 20 & 5 & WT & $\mathrm{F}$ & 8.4 \\
\hline Mlalazi & $22 / 03 / 2002$ & 31.82 & 28 & 0 & ST & $\mathrm{F}$ & nd \\
\hline Zinkwazi & $22 / 03 / 2002$ & 31.44 & 15 & 13 & ST & $\mathrm{E}$ & 6.2 \\
\hline Durban Bay & $27 / 03 / 2002$ & 31.06 & 35 & 20 & ST & nd & nd \\
\hline Mzimkulu & $03 / 04 / 2002$ & 30.46 & 5 & 11 & ST & $\mathrm{F}$ & 8.0 \\
\hline Seekoei & $04 / 03 / 2004$ & 24.91 & $\mathrm{Nd}$ & nd & WT & $\mathrm{E}$ & 7.6 \\
\hline Olifants 2 & ??/03/2004 & 18.20 & $\mathrm{Nd}$ & nd & $\mathrm{CT}$ & $\mathrm{F}$ & 6.6 \\
\hline Tsitsikamma & $21 / 03 / 2004$ & 24.44 & $\mathrm{Nd}$ & nd & WT & $E$ & 7.1 \\
\hline Olifants 3 & $04 / 08 / 2004$ & 18.20 & $\mathrm{Nd}$ & nd & $\mathrm{CT}$ & $\mathrm{F}$ & 6.6 \\
\hline Kromme & $30 / 07 / 2004$ & 24.84 & 35 & 35 & WT & $\mathrm{F}$ & 8.3 \\
\hline Great Berg 2 & $14 / 11 / 2005$ & 18.15 & 33 & 2 & $\mathrm{CT}$ & $\mathrm{F}$ & 5.1 \\
\hline
\end{tabular}

might still be sampled, the data collected and presented here are considered to be a fair representation of the benthic diatom flora to be found in South African estuaries.

\section{Materials and methods}

During the period 1998 to 2005, 27 estuaries were sampled to identify the epipelic diatoms. The details of the different sites are shown in Table 1. Diatom data collected between 2004 and 2005 (Bate and Smailes, 2008) in the St. Lucia Estuary are not included in Table 1 but are referred to where relevant to indicate the salinity tolerance of taxa that were present further north than the Nhlabane Estuary and on occasions when there were higher than normal salinity conditions.

The Mhlathuze Estuary was previously an estuarine bay but has been modified by being split into 2 sections. One is now Richards Bay Harbour and the other the much-modified 
Mhlathuze Estuary. The Nhlabane Estuary once had a large freshwater lake at its head before being cut off by a high weir. The water in the lake is used by Richards Bay Minerals in its dune-mining operation. The weir is built in dune sand, which allows a considerable freshwater flow into the estuary via groundwater, and freshwater flows abruptly into the very short estuary when there is a high rainfall event. Although the Nhlabane Estuary has been greatly modified, the data are included because it is a system that, at the time the collections were made, experienced frequent flooding events due to the engineering design of the overflow system. It therefore represents a fully freshwater-dominated system.

In the case of the Mtata Estuary, the water was loaded with fine-grained sediment from the catchment, hence many of the diatoms present may not have been recorded. The Knysna Estuary is a shallow estuarine bay without a clear longitudinal salinity gradient. The samples were collected along the length of the shoreline, from the mouth to above the N2 highway bridge. The Mkomazi Estuary was made up mostly of sand banks and had very little water flowing at the time. The result is that only a few stations could be sampled.

This estuary project followed a very specific sampling protocol that aimed to determine whether intertidal sites had a different flora to subtidal sites and whether the higher average salinity near the mouth supported a different flora to the low salinity sites near the head. The hypothesis was that, if the diatom species changed along salinity values, species might then be used as indicators of freshwater inflow to estuaries. Knowing that tidal surge causes daily changes in salinity when the mouth is open, 3 sites were sampled in addition to the mouth and head, resulting in 5 sampling sites for each estuary. This meant that 10 samples were taken from each estuary (5 inter- and 5 subtidal). Only those estuaries where 10 suitable samples were collected have been included in the data presented.

Epipelic diatoms were sampled as described by Round (1983). To obtain samples representative of different microhabitats, a length of plastic tube was drawn across the sediment and allowed to fill with a mixture of surface sediment and water. This was repeated up to 5 times in different places at each site, over a length of $1-5 \mathrm{~m}$. The mixture of sediment and water was stored in a $500 \mathrm{~m} \ell$ plastic sample container. The salinity of the water representative of each site was assessed using a calibrated refractometer on a sample from each plastic container, after the sediment had settled.

In a field laboratory, on the day of sampling, an aliquot of the sediment sample was placed in a petri dish with about $5 \mathrm{~mm}$ depth of water from the container. The sediment was allowed to settle in the petri dish for about an hour, by which time the water was usually fairly clear. Five glass slide cover slips, covering $47 \%$ of the sediment surface, were placed on top of the wet sediment. These were left in diffuse natural light for approximately $1 \mathrm{~h}$ before the cover slips were carefully removed. A period of $1 \mathrm{~h}$ had previously been shown to produce the maximum number of cells (Minne, 2003). In this way only living motile cells of epipelon that had attached to the cover slips were sampled. The 5 cover slips from each sample were placed in a glass bottle, sealed and transported to the laboratory.

To each glass bottle containing the cover slips taken from the epipelon incubations, $2 \mathrm{~m} \ell$ of saturated potassium permanganate and $2 \mathrm{~m} \ell$ of hydrochloric acid $(10 \mathrm{M})$ were added. This mixture was heated on a hotplate at approx. $60^{\circ} \mathrm{C}$ until the solution cleared. All acid-cleaned samples were washed with distilled water using 5 consecutive spins at $2000 \mathrm{r} / \mathrm{min}$ for $10 \mathrm{~min}$ (Round, 1995). The supernatant was drawn off and a $1.5 \mathrm{~m} \ell$ sample placed in a plastic microfuge tube for storage.

Permanent light microscopy slides were made using 2 drops of the diatom 'digest' placed onto a cover slip and allowed to air-dry overnight. When the cover slips were completely dry, a small amount of Naphrax ${ }^{\circledR}$ mounting medium (Northern Biological Supplies, U.K.) was dotted onto a glass microscopy slide and the cover slip placed over it. Air trapped under the slide in the Naphrax was dispersed by heating the slide at approx. $60^{\circ} \mathrm{C}$. The Naphrax was allowed to dry for approximately 1 week.

Using a television camera (JVC KY-F3) mounted on a microscope at 1000 times magnification with DIC optics, images of the species were viewed using the AnalySIS image analysis programme (C1999, Soft Imaging System GmbH). If these images did not provide enough detail for species identification, a sample was prepared for scanning electron microscope viewing (SEM, Philips XL 30).

Keys in Archibald (1983) Cholnoky (1963, 1965, 1968), Hustedt (1930), Krammer and Lange-Bertalot (1986, 1988, 1991), Lange-Bertalot and Krammer (1989), Patrick and Reimer (1966), Patrick and Reimer (1975), Round et al. (1990), Schoeman and Archibald (1976), Simonsen (1987a,b,c), Sims (1996) and Van Heurck (1896) were used to identify diatoms to species wherever possible. In some cases, where our image was not clear enough to make a definite identification or a definitive identification could not be made from the literature, this is indicated within the name provided. These cases include 'cf.', i.e. A. coffeaeformis (Adargh) Kutzing or $A$. cf. coffeaeformis. In the latter case the acronym is AMPHcfco, while for the identified species it is AMPHCOFF. In a number of cases, no identifications could be made even though the specimen was observed in a number of estuaries. Examples of this are prevalent in the genus Seminavis DG Mann where 10 taxa could not be identified. Where a species could not be identified it was provided with a species number, e.g. Seminavis sp. 01 and an image was saved which was used in all further cases where it appeared. Hence, a complete record of all the diatom taxa found in all the estuaries of South Africa are held on record in the NMMU Botany Department herbarium. In addition, small wet samples have also been retained for possible later use.

Relative abundance of the different species was determined by counting valves until a clear dominance of one or more species was revealed. For samples that did not show clear dominance of a particular species, 300 valves were counted. The relative abundance of valves, down to $\sim 3 \%$, has been included in the data set. Species with relative abundance less than $\sim 3 \%$ were ignored on the assumption that they were not part of the estuarine diatom flora that might be used to identify conditions at the time of collection.

The species data for each estuary were assembled in MS Excel files featuring the genus and species as well as the authority and an acronym. These acronyms are provided in Table 2 and are used in the examination of the results because they are shorter than the full names with their authorities. In addition to the acronyms, genus, species and a number of other details were included. The level of maximum abundance of each species at each of 5 sites, i.e. an indication of whether the species was very dominant at some sites or only present; presence or absence in cool temperate (CT), warm temperate (WT) or subtropical (ST) estuaries (Whitfield 1992); presence in subor intertidal zones (or both); the salinity at which the species was found, to indicate the salinity range; the site (mouth (1), 
head (5) or intermediate (2, 3 and 4$)$; the species salinity classification in the UK after Sims (1996), i.e. freshwater, brack or marine; and its presence or absence in each estuary (including each occasion that the estuary was sampled in the case of the Olifants, Berg and St. Lucia estuaries). The species found in the St. Lucia Estuary that were previously reported by Bate and Smailes (2008) were also included in the MS Excel file. Most of the St. Lucia sites were sampled on more than one occasion and the data are included here for comparative purposes. The salinity at each of the St. Lucia sites was not included in any calculations because at the time it was experiencing a severe drought and its inclusion in the main dataset was considered unwise because of the introduction of bias.

The data in the MS Excel files were exported into an MS Access data file which was in turn converted into 'forms' files. The data in these forms were then interrogated in detail using suitable manipulations. The 'manipulations' included an examination of the species' abundance, the salinity in which they were found, the type of estuary (POE, TOCE or Lake) and the temperature regions in which they were found.

A further MS Excel data file was assembled in which each species was recorded with respect to its level of abundance in each estuary. The data could then be interrogated on the basis of presence/absence and abundance. In the data involving salinity tolerance, only those species found on more than 3 occasions are considered as well as those that had a coefficient of variation $(\% \mathrm{CV})$ of 10 or less. The salinity groups were those of Day (1981), i.e. oligohaline (0-5 psu), mesohaline, (5-18 $\mathrm{psu})$, polyhaline (18-30 psu), euhaline (30-40 psu) or hypersaline ( $>40 \mathrm{psu})$.

Similarity of diatom taxa between estuaries or groups of estuaries was calculated using Sorenson's Similarity Index (Sorensen (1948); QS $=2 \mathrm{x}$ the number of species that were similar / the total number present in the two estuaries being compared. This same QS value was used to compare species similarity between groups of estuaries, e.g. CT vs. WT, WT vs. ST and ST vs. St. Lucia.

\section{Results}

Of the total of 333 diatom taxa identified in the 27 estuaries (Table 2), 90 could not be identified definitively to species or variety. Where uncertainty regarding the species was concerned, the prefix af. (affinity) was used, e.g. AMPHafFL which stands for a close similarity to Amphora flebilis, but with some degree of doubt. Where cf. is used it implies that the specimen 'can be compared to' but not positively, and that there was nothing in the literature examined that was a more likely match. In a number of cases there was no close similarity and 'sp' was used e.g. AMPHsp01, which implies that it was identified to the genus Amphora but not to species. It is possible that some of these 90 unidentified taxa are new to science.

The total number of taxa found in each of the estuary sites, together with the salinity at each site, is given in Table 3.

The data in Table 3 show that the salinity varied between 0 and 38 psu and indicate that the number of diatom taxa is not restricted by virtue of the range of salinity encountered, i.e., high salinity is not associated with a low number of taxa. The total number of taxa observed at each site varied between 8 and 74 , indicating that, although the taxa reported in the data were only those with abundance higher than $3 \%$, there were a great number observed.

Of the 333 taxa, 198 occurred in the intertidal sites and 198 taxa were found in subtidal sites. There were 117 taxa found in both sub- and intertidal sites. The implication here is that not all taxa may necessarily have the ability to survive in both habitats. Where it was possible to reach areas above an estuary, i.e. in the river, the diatom flora was sampled. From these few samples 8 taxa were found as dominants in both the river and in the estuary. Their details are shown in Table 4 and indicate very little similarity between the diatoms in the rivers flowing into estuaries and the diatoms in the estuaries.

Achnanthes engelbrechtii (Planothidium engelbrechtii (Cholnoky) Round and Bukhtiyarova) (Table 4) was found in the Keurbooms Estuary at Site 5, just below the river, at 2 psu. It was also found in the Olifants Estuary at intertidal and subtidal Site 3, at 14 and 26\% abundance, respectively; at subtidal Site 4 at $5 \%$, and in the Breede River site just above the estuary at $6 \%$ abundance. In St. Lucia it was found at Charters Creek at 18 psu. From these data the conclusion is that A. engelbrechtii, which was originally identified by Cholnoky (1955) from a collection of specimens from the saline waters from the Western Cape Province, can be classified as a brack species. It has been identified as being present in the Antarctic and Sub-Antarctic Southern Ocean, which means that it is both a marine, brack (AADC, 2012) and freshwater species.

Amphora holsatica was found in the river above the Mngazana Estuary (14\% abundance), at intertidal Site 4 (28\% abundance) and in the Mngazi Estuary at 8 psu (23\% abundance). In the literature it is listed as having the following characteristics (Habitat $3 \approx 30 \mathrm{mg} \cdot \ell^{-1} \mathrm{TDS}$, eutrophic $-0.53 \mathrm{mg} \cdot \ell^{-1}$ $\left.\mathrm{TPO}_{4}, 1.66 \mathrm{mg} \cdot \ell^{-1} \mathrm{TKN}\right)$ (Guiry, 2012a, 2012b). It is listed in the WoRMS Register of Marine Species (Hartley, 1986). A. holsatica, accordingly, is to be considered an oligotrophic indicator in freshwater, brack and marine environments. The Mngazana Estuary is located on the eastern seaboard of South Africa in a relatively pristine area without municipal or agricultural pollution.

Hantzschia distinctepunctata is listed in the WoRMS Register of Marine Species (John, 1983). It was found in the Swan River Estuary and is considered to be a freshwater, marine and estuarine ‘brack' species (John, 1983; Guiry, 2012b).

Navicula cincta var. leptocephala is considered to be a brackish species (Guiry and Guiry, 2012), but other references - Hendey (1974) and Hustedt (1930) - have described it as both a marine and freshwater species that has been identified from the Gulf of Mexico. It was found at 0 to 28 psu in the Keurbooms, Tsitsikamma, Sundays, Great Fish, Mlalazi and Nhlabane estuaries at all sites except Site 2, at abundances up to $50 \%$. It was present above the Sundays Estuary, in the river. It is considered to be a marine, brack and freshwater species in Australia (John, 1983).

$N$. phyllepta Kutzing is described as a brack species in AlgaeBASE (Guiry and Guiry, 2012), but is also described as a marine species (Hendey, 1974). In this study it was found in Durban Bay, the Great Fish, Olifants, Great Berg, Mlalazi, Mzimkulu, Sundays and Zinkwazi estuaries as well as in St. Lucia at Listers Point and Dead Tree Bay, at frequencies of between 4 and $83 \%$, at all sites including rivers between 0 and 34 psu, i.e. a truly adaptable species.

Nitzschia clausii is considered to be a 'non-marine' diatom (Aboal et al., 2003), yet it is listed in the WoRMS Register of Marine Species (Guiry, 2012c). Sims (1996) described it as a freshwater species, yet in this study it was not found at any river site although it was found in the estuary centre site (Site 3) or near the head, at abundances between 19 and $42 \%$ in salinity between 0 and $30 \mathrm{psu}$. Hence, while it probably is not a 
Table 2

List of the 333 epipelic diatom taxa acronyms identified from all the estuaries sampled around the South African coast These codes mainly comprise the first 4 letters of the genus plus the first 4 of the species.

\begin{tabular}{|c|c|c|c|c|c|c|c|}
\hline \multicolumn{8}{|l|}{ Diatom codes } \\
\hline ACHNAOEN & AMPHLINE & COCCSCpa & FALLTENE & NAVIBOUR & NAVIsp02 & NITZSCAL & SEMIsp01 \\
\hline ACHNBRbr & AMPHMICR & COCCSCUT & FALLSCHA & NAVIBREM & NAVIsp05 & NITZSCAP1 & SEMIsp02 \\
\hline ACHNcfpl & AMPHNORM & COCCSCsc & FALLsp01 & NAVIcfARro & NAVISUBC & NITZSIGM & SEMIsp03 \\
\hline ACHNCONS & AMPHOVaf & COCCsp01 & FALLsp02 & NAVIcfCI & NAVITENE & NITZSPAT & SEMIsp04 \\
\hline ACHNDELI & AMPHPROT & COCCsp03 & FALLsp04 & NAVIcfDE & NAVIVENE & NITZSPIC & SEMIsp05 \\
\hline ACHNENGE & AMPHPSEU & COCCsp04 & FALLsp05 & NAVIcfER & NAVIVAva & NITZsp01 & SEMIsp06 \\
\hline ACHNEXex & AMPHSPEC & COCCsp05 & FALLUMPA & NAVIcfIN & NAVIVIro & NITZsp02 & SEMIsp07 \\
\hline ACHNKUEL & AMPHsp01 & COCCsp06 & FRAGELLI & NAVIcfLI & NITZafpe & NITZsp04 & SEMIsp08 \\
\hline ACHNLEMM & AMPHsp04 & CRATHALO & FRAGINVE & NAVIcfNO & NITZANGU & NITZsp05 & SEMIsp09 \\
\hline ACHNMIgr & AMPHSTAU & CYLICLOS & FRAGSCAL & NAVIcfPE & NITZANva & NITZSPAT & STAUPACH \\
\hline ACHNMINU & AMPHSUBA & CYLIGRAC & FRUSROST & NAVIcfPH & NITZAREM & NITZVACI & STAUSPIC \\
\hline ACHNMIva & AMPHSUBL & CYMBTURG & GOMPPARV & NAVIcfSU & NITZcfag & ODENAURI & SURIATOM \\
\hline ACHNOBLO & AMPHTENE & DIPLBOMB & GEISDECU & NAVIcttd & NITZcfCO & OPEPHORS & SURIBREB \\
\hline ACHNSP01 & AMPHTERR & DIPLCAFF & GYROACUM & NAVIcfUN & NITZcfli & OPEPMARI & SURISCAL \\
\hline AMPHsp & ANOREXCE & DIPLcfbo & GYROBALT & NAVICIle & NITZFUSI & OPEPMINU & SURIBRbr \\
\hline AMPHABLU & ANEUTUSC & DIPLcfNO & GYROcfsp & NAVICINC & NITZcffu & PARLBERK & SURIsp01 \\
\hline AMPHACUT & ASTABAHU & DIPLDIDY & GYROEXIM & NAVICLAM & NITZcfov & PARLDELO & SURISTRI \\
\hline AMPHANGU & ASTABREM & DIPLELLI & GYROFAar & NAVICONS & NITZcfps & PARLsp01 & SYNEFASC \\
\hline AMPHARCU & ASTAcfba & DIPLINTE & GYROPRcl & NAVICRYP & NITZcfsi & PARLsp02 & TABIFLOC \\
\hline AMPHCARO & ASTAIKS & DIPLMINI & GYROSCAL & NAVIDEHI & NITZCLAU & PARLsp03 & TABUKTEN \\
\hline AMPHCAST & ASTAPUNC & DIPLOBLO & GYROsp01 & NAVIDIVE & NITZCLOS & PARLsp04 & TRYBAPIC \\
\hline AMPHcfco & ASTAsp01 & DIPLPARM & HANTDIST & NAVIDUER & NITZDISS & PETRGEMM & TRYBCOAR \\
\hline AMPHcfer & ASTAsp02 & DIPLpapa & HANTVivi & NAVIERIF & NITZDIdi & PETRHUME & TRYBCONS \\
\hline AMPHcfte & ASTAsp03 & DIPLPUEL & HASLCRUC & NAVIEXIL & NITZEROS & PETRMARI & TRYBHUNG \\
\hline AMPHcfcy & BACISOCI & DIPLSMsm & HASLNAUT & NAVIFRAC & NITZFASC & PINNSUBC & TRYBLITT \\
\hline AMPHafFL & BACIPApa & DIPLSMvar & HASLcfOS & NAVIGERM & NITZFONT & PINNYARR & \\
\hline AMPHCOap & BACIPAXI & DIPLsp02 & HASLOSTR & NAVIGREG & NITZFREQ & PLACcfCL & \\
\hline AMPHCOFF & BERKMICA & DIPLsp03 & HASLsp01 & NAVIGRva & NITZFRgr & PLACcfEL & \\
\hline AMPHCOGN & BERKRUTI & DIPLSTRO & HASLsp02 & NAVIHAST & NITZGRAN & PLACsp01 & \\
\hline АMРНCOMM & BERKFENI & DIPLVAva & HASLsp03 & NAVIHEIM & NITZHOLS & PLAGMAXI & \\
\hline AMPHCOv1 & BERKSCOP & DONKsp01 & HASLSPIC & NAVILIBO & NITZINCO & PLAGTAYR & \\
\hline AMPHCOv2 & BERKsp & ENTOALAT & HIPPsp & NAVIMOLL & NITZLINK & PLANafen & \\
\hline AMPHCRAS & BIRELUCE & ENTOANGU & MASTEXIG & NAVINORM & NITZLITT & PLANDELI & \\
\hline АМРНСУМВ & BRACESTO & ENTOPApa & MASTBRAU & NAVIPAEN & NITZLORE & PLEUAEST & \\
\hline AMPHDECU & BRACsp01 & ENTOcfpu & MASTPUpu & NAVIPERM & NITZFRUS & PLEUDELI & \\
\hline AMPHEUNO & CALcfHY & ENTOPAdu & NAVIABSC & NAVIPHYL & NITZFUSI & PLEUSALI & \\
\hline AMPHEXIG & CALOLIBE & ENTOPALU & NAVIADSI & NAVIPHYLa & NITZHUST & PLEUsp01 & \\
\hline AMPHEXIL & COCCcfAR & ENTOSP01 & NAVIAMMO & NAVIPSEU & NITZHYBR & PROSBUbu & \\
\hline AMPHGRAC & COCCCONV & ENTOSP02 & NAVIARar & NAVIRAMO & NITZLORE & RHOPGIBB & \\
\hline AMPHHELE & COCCDISC & EUNO cf. so & NAVIARro & NAVIRAmu & NITZOVAL & RHOPcfmu & \\
\hline AMPHHOLS & COCCENGE & EUNOINTE & NAVIBAHU & NAVIROST & NITZPALE & RHOPMUSC & \\
\hline AMPHJOST & COCCPLAC & FALLCLEP & NAVIBESA & NAVISALI & NITZPELL & SEMIANGU & \\
\hline AMPHLAEV & COCCPLeu & FALLCRYP & NAVIAEQU & NAVIsp & NITZPERS & SEMICYMB & \\
\hline AMPHLIBY & COCCPLli & FALLFLOR & NAVIBORN & NAVIsp01 & NITZREVE & SEMIsp & \\
\hline
\end{tabular}

marine species under South African conditions, it can tolerate high brack conditions. Nitzschia clausii was dominant at $76 \%$ at a river site above the Goukamma Estuary (WT) and at 29\% at Site 4 in 14 psu, but also at $9 \%$ at Site 5 (i.e. just below the river) in the Great Brak Estuary at 5 psu. From these data $N$. clausii seems to generally retain its freshwater status (Sims, 1996) except for occasionally being found at intertidal sites close to the river inflow. The significance of being found at intertidal rather than at subtidal sites may relate to the former generally having lower salinity because freshwater flows over water of a higher salt content.

For N. palea, ecological information (Kelly et al., 2005) suggests that this species is benthic in freshwater; in the UK the optimum filterable phosphate concentration was $0.35-$ $1 \mathrm{mg} \cdot \ell^{-1}$, while in other European countries the species is tolerant of very heavy pollution. In the UK it is considered to be a freshwater species (Sims, 1996) while in The Netherlands it is considered to be brackish. In this study N. palea was found 


\begin{tabular}{|c|c|c|c|c|c|c|c|c|c|c|c|}
\hline \multicolumn{12}{|c|}{$\begin{array}{l}\text { Table } 3 \\
\text { The abbreviated estuary name (in alphabetical order), salinity at the time of sampling and the number of diatom } \\
\text { taxa found during the study. (Ber = Great Berg; Bre = Breede; Bush= Bushmans; GFish = Great Fish; Gouk =Goukou; } \\
\text { Gouo = GouKou; Keur = Keurbooms; Kowi = Kowie; Krom = Krom; Mlal= Mlalazi; Mnga = Mngazana; Mzim = } \\
\text { Mzimkulu; Zink = Zinkwazi; I= Intertidal; S=Subtidal, } 1 \text { = mouth site; } 5 \text { = head site; } 2,3 \text { and } 4 \text { intermediate sites } \\
\text { between the mouth and the head; Taxa= Number of taxa found. }\end{array}$} \\
\hline \multicolumn{3}{|c|}{ Salinity } & \multicolumn{3}{|c|}{\begin{tabular}{|l|} 
Salinity \\
\end{tabular}} & \multicolumn{3}{|c|}{$\begin{array}{l}\text { Salinity } \\
\end{array}$} & \multicolumn{3}{|c|}{\begin{tabular}{|c|} 
Salinity \\
\end{tabular}} \\
\hline Estuary & (psu) & Taxa & Estuary & $\begin{array}{l}\text { Salinity } \\
\text { (psu) }\end{array}$ & Taxa & Estuary & $\begin{array}{c}\text { Salinity } \\
\text { (psu) }\end{array}$ & Taxa & Estuary & $\begin{array}{c}\text { Salinity } \\
\text { (psu) }\end{array}$ & Taxa \\
\hline BerI1 & 24 & 47 & GoukI1 & 29 & 20 & KromI1 & 35 & 22 & OlI1 & 24 & 31 \\
\hline BerI2 & 16 & 35 & GoukI2 & 18 & 11 & KromI2 & 35 & 32 & OlI2 & 16 & 21 \\
\hline BerI3 & 12 & 56 & GoukI3 & 22 & 14 & KromI3 & 35 & 18 & OlI3 & 12 & 16 \\
\hline BerI4 & 5 & 45 & GoukI4 & 14 & 25 & KromI4 & 35 & 36 & OlI4 & 5 & 20 \\
\hline BerI5 & 1 & 40 & GoukI5 & 5 & 30 & KromI5 & 35 & 20 & OlI5 & 1 & 22 \\
\hline BerS1 & 26 & 41 & GoukS1 & 25 & 28 & KromS1 & 35 & 33 & OlS1 & 26 & 25 \\
\hline BerS2 & 20 & 25 & GoukS2 & 31 & 16 & KromS2 & 35 & 50 & OlS2 & 20 & 10 \\
\hline BerS3 & 14 & - & GoukS3 & 33 & 28 & KromS3 & 35 & 50 & OlS3 & 14 & 10 \\
\hline BerS4 & 9 & 24 & GoukS4 & 30 & 21 & KromS4 & 35 & 40 & OlS4 & 9 & 11 \\
\hline BerS5 & 1 & 34 & GoukS5 & 10 & 11 & KromS5 & 35 & 34 & OlS5 & 1 & 16 \\
\hline BreI1 & 5 & - & GouoI1 & 20 & 32 & MlalI1 & 28 & 42 & SundI1 & 23 & 45 \\
\hline BreI2 & 4 & 24 & GouoI2 & 19 & 54 & MlalI2 & 24 & 32 & SundI2 & 16 & 30 \\
\hline BreI3 & 3 & 8 & GouoI3 & 15 & 17 & MlalI3 & 24 & 16 & SundI3 & 11 & 28 \\
\hline BreI4 & 2 & 19 & GouoI4 & 14 & 15 & MlalI4 & 33 & 19 & SundI4 & 4 & 18 \\
\hline BreI5 & 0 & 32 & GouoI5 & 5 & 33 & MlalI5 & 0 & 30 & SundI5 & 3 & 36 \\
\hline BreS1 & 7 & 36 & GouoS1 & 25 & 48 & MlalS1 & 34 & 24 & SundS1 & 24 & 30 \\
\hline BreS2 & 5 & 22 & GouoS2 & 27 & 43 & MlalS2 & 34 & 41 & SundS2 & 15 & 24 \\
\hline BreS3 & 3 & 19 & GouoS3 & 14 & 34 & MlalS3 & 33 & 26 & SundS3 & 10 & 36 \\
\hline BreS4 & 2 & 13 & GouoS4 & 14 & 25 & MlalS4 & 33 & 32 & SundS4 & 4 & 19 \\
\hline BreS5 & 0 & - & GouoS5 & 10 & 10 & MlalS5 & 0 & 28 & SundS5 & 2 & 20 \\
\hline BushI1 & 34 & 73 & KeurI1 & 34 & 24 & MngaI1 & 35 & 62 & SwarI1 & 38 & 51 \\
\hline BushI2 & 34 & 60 & KeurI2 & 38 & 62 & MngaI2 & 27 & 40 & SwarI2 & 35 & 37 \\
\hline BushI3 & 33 & 74 & KeurI3 & 19 & 26 & MngaI3 & 30 & 40 & SwarI3 & 29 & 58 \\
\hline BushI4 & 33 & 48 & KeurI4 & 5 & 10 & MngaI4 & 25 & 40 & SwarI4 & 25 & 54 \\
\hline BushI5 & 32 & 50 & KeurI5 & 2 & 22 & MngaI5 & 23 & 24 & SwarI5 & 21 & 51 \\
\hline BushS1 & 36 & 60 & KeurS1 & 31 & 47 & MngaS1 & 35 & 62 & SwarS1 & 38 & 42 \\
\hline BushS2 & 34 & 65 & KeurS2 & 32 & 50 & MngaS2 & 32 & - & SwarS2 & 36 & 65 \\
\hline BushS3 & 34 & 60 & KeurS3 & 27 & 21 & MngaS3 & 34 & 40 & SwarS3 & 31 & 64 \\
\hline BushS4 & 34 & 60 & KeurS4 & 9 & 35 & MngaS4 & 29 & 40 & SwarS4 & 33 & 41 \\
\hline BushS5 & 33 & 60 & KeurS5 & 2 & 21 & MngaS5 & 27 & 20 & SwarS5 & 27 & 36 \\
\hline GFisI1 & 18 & 34 & KowiI1 & 35 & - & MzimI1 & 5 & 15 & ZinkI1 & 15 & 11 \\
\hline GFisI2 & 13 & 23 & KowiI2 & 32 & 56 & MzimI2 & 5 & 23 & ZinkI2 & 14 & 19 \\
\hline GFisI3 & 10 & 17 & Kowil3 & 29 & 61 & MzimI3 & 4 & 36 & ZinkI3 & 14 & 21 \\
\hline GFisI4 & 5 & 30 & KowiI4 & 25 & 42 & MzimI4 & 5 & 34 & ZinkI4 & 12 & 10 \\
\hline GFisI5 & 0 & 20 & KowiI5 & 20 & 60 & MzimI5 & 11 & 40 & ZinkI5 & 13 & 22 \\
\hline GFisS1 & 32 & 18 & KowiS1 & 35 & 61 & MzimS1 & 6 & 52 & ZinkS1 & 15 & 18 \\
\hline GFisS2 & 35 & 27 & KowiS2 & 35 & 57 & MzimS2 & 33 & 14 & ZinkS2 & 14 & 33 \\
\hline GFisS3 & 30 & 15 & KowiS3 & 30 & 53 & MzimS3 & 30 & 48 & ZinkS3 & 14 & 36 \\
\hline GFisS4 & 26 & 21 & KowiS4 & 29 & 71 & MzimS4 & 14 & 47 & ZinkS4 & 12 & 38 \\
\hline GFisS5 & 0 & 0 & KowiS5 & 26 & 47 & MzimS5 & 8 & 56 & ZinkS5 & 13 & 28 \\
\hline
\end{tabular}

in the Goukamma Estuary at intertidal Site 3 in 22 psu at an abundance of $17 \%$. It was also found in the river above the Mngazana Estuary at an abundance of $29 \%$. For a freshwater species to be found at moderate abundance in a closed estuary mid-way to the sea implies that it has some tolerance to salt. From the data in this South African collection it must be considered as a freshwater and brack species.
Because the genus Seminavis was not identified in this study to the level of species no details from the literature are available. Round et al. (1990 p. 572) consider the genus to be 'a small genus of marine epipelon and epiphyton'. In this study it was present in both sub- and intertidal sites of the cool and warm temperate regions. It was not found in the subtropical estuaries but was found in the subtropical St. 


\begin{tabular}{|c|c|c|c|c|c|c|c|c|}
\hline \multicolumn{9}{|c|}{$\begin{array}{l}\text { Table } 4 \\
\text { Diatom species abundance at different estuary sites and from river sediment immediately above the head of } \\
\text { the estuary. (1-5 = estuary site; 'Low' refers to the PSU at the river site and 'High' is the highest salinity at } \\
\text { which the taxon was found). }\end{array}$} \\
\hline \multirow[t]{2}{*}{ Taxon } & \multicolumn{6}{|c|}{$\%$ abundance at site } & \multicolumn{2}{|c|}{ Salinity at site (psu) } \\
\hline & 1 & 2 & 3 & 4 & 5 & River & Low & High \\
\hline A. engelbrechtii Cholnoky & & & 26 & 5 & 16 & 6 & 0 & 2 \\
\hline Amphora holsatica Hustedt & & & & 23 & & 14 & 0 & 8 \\
\hline Hantzschia distinctepunctata Hustedt & 36 & & 23 & 50 & & 45 & 0 & 28 \\
\hline Navicula cincta var. lepticephala & & & 17 & & & 6 & 0 & 33 \\
\hline N. phyllepta Kutzing & 83 & 78 & 4 & 66 & 52 & 25 & 0 & 34 \\
\hline Nitzschia. clausii Hantzsch & & & & 29 & 9 & 76 & 0 & 26 \\
\hline N. palea (Kutzing) W.Smith & & & 17 & & & 29 & 0 & 22 \\
\hline Seminavis sp. 04 & & 10 & & 5 & 10 & 15 & 0 & 40 \\
\hline
\end{tabular}

Lucia sites at abundances between 5 and $15 \%$ in brack water. Tolerance to salinity was $0-40 \mathrm{psu}$. It may also survive in marine waters but was never found at the mouth of any estuary. Seminavis sp. 04 was dominant at $15 \%$ abundance in the river above the Olifants Estuary in June 2001. It was also found in the Seekoei Estuary at subtidal Site 5 (just below the river), in the Breede Estuary intertidal Site 2 at 24 psu (10\%), in the Kowie Estuary at subtidal Site 4 at 29 psu (4.5\%), in the Sundays Estuary at subtidal Site 2 at 15 psu (6.5\%), in St. Lucia (Hells Gate) at $40 \mathrm{psu}(22 \%)$. It is therefore considered to be well adapted to both fresh and hypersaline water. The data in Table 4 indicate that the same diatom species occur in the lower, middle and upper reaches of estuaries even though there was a salinity gradient.

Only 14 taxa were found to co-occur in all cool temperate (CT), warm temperate (WT), subtropical (ST) and St. Lucia sites. These 14 taxa are ubiquitous and therefore considered to be of no values as a temperature indicator in South African estuaries (Table 5).

- Achnanthes engelbrechtii Cholnoky (Planothidium engelbrechtii (Chnolky) Round and Bukhityarova) was dominant at Sites 3-5 and in a river site but always at relatively low abundance (5-26\%). It was present in both sub- and intertidal sites at salinity values of $0-2$ psu, but in St. Lucia it was found at 18 psu.

- Amphora acutiscula was dominant at all sites except in a river site (abundance 8-78\%). It was present in both suband intertidal sites at salinity values of $1-38$ psu while in St. Lucia it was found at $14-15 \mathrm{psu}$.

- A. coffeaeformis was dominant at all sites except a river site (abundance 22-63\%). It was present in both sub- and intertidal sites at salinity values of 0-39 psu and in St. Lucia it was found at 4-31 psu.

- A. subacutiscula was dominant at all sites except a river site (abundance 13-48\%). It was present in both sub- and intertidal sites at salinity values of 2-39 psu while in St. Lucia it was found at $56 \mathrm{psu}$.

- Bacillaria paxillifera was found at all sites except Site 2 and a river site (abundance 13-46\%). It was present in both sub- and intertidal sites at salinity values of $0-26$ psu but in St. Lucia it was only found at 2 psu. Sims (1996) classified it as a brack species in the UK.

- Diploneis smithii v. smithii was dominant at all sites except a river site (abundance 6-20\%). It was present in both suband intertidal sites at salinity values of $2-28$ psu and in St. Lucia it was found between 1-26 psu.

- Navicula sp. 02 was found at Sites 1,3 and 4 (abundance

\begin{tabular}{|l|l|}
\hline \multicolumn{2}{|c|}{$\begin{array}{c}\text { Table } \mathbf{5} \\
\text { The 'ubiquitous' diatom species found in the estuaries } \\
\text { of all South African temperature regions }\end{array}$} \\
\hline Acronym & Genus, species, Authority \\
\hline ACHNENGE & Achnanthes engelbrechtii Cholnoky \\
\hline \multicolumn{1}{|c|}{ “ } & $\begin{array}{l}\text { Planothidium engelbrechtii } \text { (Chnolky) } \\
\text { Round and Bukhityarova }\end{array}$ \\
\hline AMPHACUT & Amphora acutiuscula Kutzing \\
\hline AMPHCOFF & A. coffeaeformis (Adargh) Kutzing \\
\hline AMPHSUBA & A. subacutiuscula Schoeman \\
\hline BACIPAXI & Bacillaria paxillifera (O.F. Müller) Hendey \\
\hline DIPLSMsm & D. smithii (Brebisson) Cleve var. smithii \\
\hline NAVIsp02 & Navicula J.B.M. Bory de St. Vincent sp. 02 \\
\hline NAVIABSC & N. abscondita Hustedt \\
\hline NAVICINC & N. cincta (Ehr.) Ralfs in Pritchard \\
\hline NAVIGREG & N. gregaria Donkin \\
\hline NAVIPHYL & N. phyllepta Kutzing \\
\hline NAVISALI & N. salinicola Hustedt \\
\hline NITZFRUS & Nitzschia frustulum (Kutzing) Grunow \\
\hline NITZSIGM & N. sigma (Kutzing)W.M.Smith \\
\hline
\end{tabular}

5-11\%) in both sub- and intertidal sites at 0-38 psu and in St. Lucia at $12-38$ psu.

- $\quad$. abscondita was dominant at Sites 3-5 only (abundance 5-15\%). It was present in both sub- and intertidal sites at salinity values of 12-38 psu and was found in St. Lucia at between 29 and 138 psu.

- $\quad$. cincta was dominant at Sites 3 and 5 only (abundance $19-42 \%)$. It was present in both sub- and intertidal sites at salinity values of 0-39 psu and in St. Lucia at 6-16 psu.

- $\quad$. gregaria was by far the most common taxon present in the whole study. It was dominant at all sites (1-5) except a river site (abundance 45-83\%). It was present in both suband intertidal sites at salinity values of $0-39$ psu and in St. Lucia at 24 psu.

- N. phyllepta was dominant at all sites and a river site (abundance 4-83\%). It was present in both sub- and intertidal sites at salinity values of $0-34$ psu and in St. Lucia it was found at 7-24 psu. It is recorded as a freshwater diatom in the British Isles (Sims, 1996).

- $\quad$. salinicola was dominant at all sites (1-5) except a river site (abundance 5-57\%). It was present in both sub- and intertidal sites at salinity values of 0-38 psu and in St. Lucia it was found at $4-133$ psu. 
Table 6

Salinity data for the taxa found at 3 or more sites in all temperature regions. The minimum of 3 sites was used to facilitate the calculation of the SD. (SD= standard deviation, TOCE = Temporarily Open/Closed Estuary, POE = Permanently Open

Estuary, Oligo = oligohaline (0-5 psu), Meso = mesohaline, $(5-18 \mathrm{psu})$, Poly $=$ polyhaline $(18-30 \mathrm{psu})$, Eu $=$ euhaline $(30-40 \mathrm{psu})$ and Hyper = hypersaline (>40 psu) (Day, 1981). StL indicates that the taxon was also found in Lake St. Lucia).

\begin{tabular}{|l|l|l|l|l|l|l|l|l|l|l|l|l|l|l|}
\hline Acronym & $\mathbf{n}$ & Mean & Min. & Max. & SD & TOCE & POE & FW & Oligo & Meso & Poly & Eu & Hyper & StL \\
\hline
\end{tabular}

\begin{tabular}{|c|c|c|c|c|c|c|c|c|c|c|c|c|c|c|}
\hline & & & & & & & & & & & & & & \\
\hline ACHNCONS & 3 & 7 & 2 & 10 & 4 & $\mathrm{x}$ & $\mathrm{x}$ & & & $\mathrm{x}$ & & & & \\
\hline aCHNDELI & 12 & 26 & 10 & 38 & 9 & $\mathrm{x}$ & $\mathrm{x}$ & & & & $\mathrm{x}$ & & & \\
\hline aCHNMIgr & 4 & 27 & 23 & 34 & 5 & & $\mathrm{x}$ & & & & $\mathrm{x}$ & & & \\
\hline aMPHACUT & 13 & 26 & 2 & 39 & 10 & $\mathrm{x}$ & $\mathrm{x}$ & & & & $\mathrm{x}$ & & & $\mathrm{x}$ \\
\hline AMPHARCU & 5 & 29 & 26 & 35 & 4 & $\mathrm{x}$ & $\mathrm{x}$ & & & & $\mathrm{x}$ & & & \\
\hline aMPHCAST & 3 & 25 & 9 & 35 & 14 & & $\mathrm{x}$ & & & & $\mathrm{x}$ & & & \\
\hline aMPHCOFF & 37 & 20 & 0 & 36 & 11 & $\mathrm{x}$ & $\mathrm{x}$ & & & & $\mathrm{x}$ & & & $\mathrm{x}$ \\
\hline AMPHCOGN & 11 & 14 & 0 & 35 & 13 & $\mathrm{x}$ & $\mathrm{x}$ & $\mathrm{x}$ & & $\mathrm{x}$ & & & & \\
\hline AMPHCOv2 & 4 & 26 & 0 & 35 & 17 & & $\mathrm{x}$ & & & & $\mathrm{x}$ & & & \\
\hline aMPHEXIG & 8 & 13 & 0 & 38 & 13 & $\mathrm{x}$ & $\mathrm{x}$ & & & $\mathrm{x}$ & & & & $\mathrm{x}$ \\
\hline AMPHLAEV & 7 & 17 & 0 & 35 & 17 & $\mathrm{x}$ & $\mathrm{x}$ & & & $\mathrm{x}$ & & & & \\
\hline aMPHSUBA & 24 & 24 & 0 & 39 & 13 & $\mathrm{x}$ & $\mathrm{x}$ & & & & $\mathrm{x}$ & & & $\mathrm{x}$ \\
\hline AMPHSUBL & 19 & 23 & 0 & 39 & 15 & & $\mathrm{x}$ & & & & $\mathrm{x}$ & & & \\
\hline aMPHTENE & 5 & 21 & 9 & 28 & 7 & $\mathrm{x}$ & $\mathrm{x}$ & & & & $\mathrm{x}$ & & & \\
\hline aSTAsp01 & 5 & 26 & 14 & 34 & 8 & & $\mathrm{x}$ & & $\mathrm{x}$ & & $\mathrm{x}$ & & & \\
\hline bACIPAXI & 13 & 6 & 0 & 26 & 8 & $\mathrm{x}$ & $\mathrm{x}$ & & & $\mathrm{x}$ & & & & $\mathrm{x}$ \\
\hline BERKRUTI & 3 & 30 & 21 & 38 & 9 & & $\mathrm{x}$ & & & & $\mathrm{x}$ & & & $\mathrm{x}$ \\
\hline COCCPLAC & 3 & 4 & 0 & 7 & 4 & $\mathrm{x}$ & $x$ & & $\mathrm{x}$ & & & & & $\mathrm{x}$ \\
\hline COCCPLeu & 4 & 4 & 1 & 10 & 4 & & $\mathrm{x}$ & & $\mathrm{x}$ & & & & & $\mathrm{x}$ \\
\hline CYLICLOS & 11 & 26 & 11 & 39 & 10 & & $\mathrm{x}$ & & & & $\mathrm{x}$ & & & $\mathrm{x}$ \\
\hline CYLIGRAC & 5 & 20 & 5 & 34 & 14 & & $\mathrm{x}$ & & & & $\mathrm{x}$ & & & \\
\hline dIPLELLI & 11 & 8 & 0 & 20 & 7 & & $\mathrm{x}$ & & & $\mathrm{x}$ & & & & $\mathrm{x}$ \\
\hline DIPLPUEL & 3 & 18 & 13 & 24 & 6 & $\mathrm{x}$ & $\mathrm{x}$ & & & $\mathrm{x}$ & & & & \\
\hline dIPLSMsm & 11 & 14 & 1 & 28 & 9 & $\mathrm{x}$ & $\mathrm{x}$ & & & $\mathrm{x}$ & & & & $\mathrm{x}$ \\
\hline DONKSP01 & 3 & 24 & 14 & 33 & 10 & & $\mathrm{x}$ & & & & $\mathrm{x}$ & & & \\
\hline eNTOPApa & 4 & 25 & 7 & 34 & 12 & & $\mathrm{x}$ & & & & $\mathrm{x}$ & & & \\
\hline fALLsp01 & 4 & 17 & 7 & 31 & 11 & & $\mathrm{x}$ & & & $\mathrm{x}$ & & & & $\mathrm{x}$ \\
\hline FALLTENE & 3 & 7 & 0 & 13 & 7 & $\mathrm{x}$ & $\mathrm{x}$ & & & $\mathrm{x}$ & & & & $\mathrm{x}$ \\
\hline FRAGELLI & 4 & 13 & 1 & 38 & 17 & & $\mathrm{x}$ & & & $\mathrm{x}$ & & & & \\
\hline gYROACUM & 8 & 26 & 7 & 35 & 10 & $\mathrm{x}$ & $\mathrm{x}$ & & & & $\mathrm{x}$ & & & \\
\hline gYROFAar & 6 & 21 & 5 & 35 & 12 & & $\mathrm{x}$ & & & & $\mathrm{x}$ & & & \\
\hline gYROPRcl & 3 & 20 & 14 & 26 & 6 & & $\mathrm{x}$ & & & & $\mathrm{x}$ & & & $\mathrm{x}$ \\
\hline GYROSCAL & 3 & 13 & 0 & 34 & 18 & & $\mathrm{x}$ & & & $\mathrm{x}$ & & & & $\mathrm{x}$ \\
\hline HANTDIST & 3 & 13 & 5 & 28 & 13 & $\mathrm{x}$ & $\mathrm{x}$ & & & $\mathrm{x}$ & & & & \\
\hline hASLCRUC & 4 & 33 & 29 & 35 & 3 & & $\mathrm{x}$ & & & & & $\mathrm{x}$ & & \\
\hline HASLOSTR & 11 & 27 & 14 & 38 & 7 & & $\mathrm{x}$ & & & & $\mathrm{x}$ & & & \\
\hline NAVIABSC & 3 & 17 & 0 & 38 & 19 & & $\mathrm{x}$ & & & $\mathrm{x}$ & & & & $\mathrm{x}$ \\
\hline NAVIARar & 5 & 19 & 1 & 35 & 15 & $\mathrm{x}$ & $\mathrm{x}$ & & & & $\mathrm{x}$ & & & \\
\hline nAVIBESA & 4 & 30 & 24 & 35 & 5 & & $\mathrm{x}$ & & & & & $\mathrm{x}$ & & \\
\hline nAVIBREM & 3 & 11 & 2 & 27 & 14 & $\mathrm{x}$ & $\mathrm{x}$ & & & $\mathrm{x}$ & & & & \\
\hline NAVIcfER & 4 & 25 & 20 & 28 & 4 & $\mathrm{x}$ & $\mathrm{x}$ & & & & $\mathrm{x}$ & & & \\
\hline nAVIcfUN & 5 & 17 & 5 & 39 & 13 & & $\mathrm{x}$ & & & $\mathrm{x}$ & & & & \\
\hline nAVICINC & 4 & 19 & 4 & 30 & 12 & & $\mathrm{x}$ & & & & $\mathrm{x}$ & & & $\mathrm{x}$ \\
\hline NAVIDEHI & 5 & 23 & 10 & 38 & 13 & & $\mathrm{x}$ & & & & $\mathrm{x}$ & & & $\mathrm{x}$ \\
\hline NAVIERIF & 3 & 12 & 1 & 33 & 18 & $\mathrm{x}$ & $\mathrm{x}$ & & & $\mathrm{x}$ & & & & \\
\hline nAVIGREG & 80 & 21 & 0 & 39 & 12 & $\mathrm{x}$ & $\mathrm{x}$ & $\mathrm{x}$ & & & $\mathrm{x}$ & & & $\mathrm{x}$ \\
\hline NAVINORM & 5 & 13 & 12 & 14 & 1 & & $\mathrm{x}$ & & & $\mathrm{x}$ & & & & \\
\hline NAVIPHYL & 14 & 18 & 3 & 34 & 12 & $\mathrm{x}$ & $\mathrm{x}$ & & & $\mathrm{x}$ & & & & $\mathrm{x}$ \\
\hline NAVISALI & 27 & 26 & 0 & 38 & 9 & $\mathrm{x}$ & $\mathrm{x}$ & & & & $\mathrm{x}$ & & & $\mathrm{x}$ \\
\hline
\end{tabular}




\begin{tabular}{|c|c|c|c|c|c|c|c|c|c|c|c|c|}
\hline NAVIsp01 & 3 & 33 & 33 & 34 & 1 & & $\mathrm{x}$ & & & & $\mathrm{x}$ & \\
\hline nAVIsp02 & 5 & 33 & 26 & 38 & 5 & & $\mathrm{x}$ & & & & $\mathrm{x}$ & $\mathrm{x}$ \\
\hline NAVISUBC & 4 & 16 & 10 & 23 & 5 & & $\mathrm{x}$ & & $\mathrm{x}$ & & & \\
\hline NAVITENE & 8 & 16 & 2 & 32 & 12 & $\mathrm{x}$ & $\mathrm{x}$ & & $\mathrm{x}$ & & & \\
\hline nITZafpe & 10 & 17 & 1 & 35 & 14 & & $\mathrm{x}$ & & $\mathrm{x}$ & & & \\
\hline nITZANGU & 5 & 30 & 25 & 34 & 4 & & $\mathrm{x}$ & & & & $\mathrm{x}$ & \\
\hline nITZANva & 3 & 34 & 28 & 38 & 5 & & $\mathrm{x}$ & & & & $\mathrm{x}$ & \\
\hline NITZcfLI & 6 & 32 & 26 & 35 & 4 & $\mathrm{x}$ & $\mathrm{x}$ & & & & $\mathrm{x}$ & \\
\hline nITZFRUS & 13 & 29 & 18 & 38 & 7 & $\mathrm{x}$ & $\mathrm{x}$ & & & $\mathrm{x}$ & & $\mathrm{x}$ \\
\hline NITZLITT & 3 & 14 & 10 & 18 & 4 & & $\mathrm{x}$ & & $\mathrm{x}$ & & & \\
\hline nITZPELL & 3 & 21 & 0 & 34 & 19 & $\mathrm{x}$ & $\mathrm{x}$ & & & $\mathrm{x}$ & & \\
\hline NITZSCAL & 3 & 21 & 14 & 34 & 11 & $\mathrm{x}$ & $\mathrm{x}$ & & & $\mathrm{x}$ & & $\mathrm{x}$ \\
\hline NITZSIGM & 5 & 14 & 0 & 34 & 18 & & $\mathrm{x}$ & & $\mathrm{x}$ & & & $\mathrm{x}$ \\
\hline OPEPHORS & 3 & 33 & 31 & 34 & 2 & & $\mathrm{x}$ & & & & $\mathrm{x}$ & \\
\hline pARLBERK & 6 & 26 & 4 & 38 & 14 & $\mathrm{x}$ & $\mathrm{x}$ & & & $\mathrm{x}$ & & \\
\hline PARLDELO & 4 & 9 & 0 & 15 & 7 & & $\mathrm{x}$ & & $\mathrm{x}$ & & & \\
\hline pARLsp01 & 3 & 19 & 10 & 30 & 10 & $\mathrm{x}$ & $\mathrm{x}$ & & & $\mathrm{x}$ & & \\
\hline pLAGTAYR & 4 & 30 & 23 & 34 & 5 & & $\mathrm{x}$ & & & & $\mathrm{x}$ & \\
\hline pLANDELI & 9 & 29 & 14 & 39 & 8 & $\mathrm{x}$ & $\mathrm{x}$ & & & $\mathrm{x}$ & & $\mathrm{x}$ \\
\hline PLEUDELI & 13 & 17 & 1 & 33 & 12 & $\mathrm{x}$ & $\mathrm{x}$ & $\mathrm{x}$ & $\mathrm{x}$ & & & \\
\hline pROSBUbu & 4 & 30 & 21 & 35 & 6 & & $\mathrm{x}$ & & & $\mathrm{x}$ & & \\
\hline sEMIsp03 & 7 & 28 & 14 & 35 & 8 & & $\mathrm{x}$ & & & $\mathrm{x}$ & & \\
\hline sEMIsp04 & 4 & 23 & 15 & 29 & 6 & $\mathrm{x}$ & $\mathrm{x}$ & & & $\mathrm{x}$ & & $\mathrm{x}$ \\
\hline SEMIsp05 & 3 & 24 & 15 & 33 & 9 & $\mathrm{x}$ & $\mathrm{x}$ & & & $\mathrm{x}$ & & \\
\hline sURIATOM & 8 & 22 & 0 & 38 & 12 & & $\mathrm{x}$ & & & $\mathrm{x}$ & & \\
\hline tRYBCONS & 6 & 24 & 10 & 35 & 10 & $\mathrm{x}$ & $\mathrm{x}$ & & & $\mathrm{x}$ & & \\
\hline
\end{tabular}

- Nitzschia frustulum was dominant at all sites (1-5) except a river site (abundance 8-20\%). It was present in both suband intertidal sites at salinity values of 18-38 psu and in St. Lucia at 1-32 psu.

- $\quad$. sigma was found only at Sites 2-4 and not at a river site (abundance 7-21\%). It was present in both sub- and intertidal sites at salinity values of $0-34$ psu and in St. Lucia at 16 psu.

The average salinity of intertidal sites was lower (19.5 psu) than the subtidal sites ( $23.3 \mathrm{psu})(p=0.026)$, although there was a wide range of $0-39$ psu in both inter- and subtidal sites in different estuaries. In permanently open estuaries (POEs) the salinity might be expected to range from fresh to seawater However, the estuaries included in this study were from both POEs and TOCE's. In some of the latter, because of very low freshwater inflow, the salinity at the head was almost as high as that at the mouth (see Table 4). Hence, presumably the range of taxa found at different sites reflects the ecological conditions present at the time of collection.

The data in Table 6 show the mean and the salinity ranges for the 75 individual taxa where $n$ was equal to or greater than 3 . These results show that only 4 taxa can be considered oligohaline, 25 mesohaline, 38 polyhaline, 12 euhaline, and none hypersaline. Many of the total number, however, were present in the hypersaline conditions found in Lake St. Lucia during the drought (Bate and Smailes, 2008). Chauvenet's Criterion was used to detect any outlier data but none of the salinity data where $n$ was $>3$ could be discarded in this way. The implications of these data are that salinity in South African estuaries is not well predicted by the majority of the epipelic diatom community. Day's (1981) salinity ranges are spaced between 5 and 13 psu apart and, using those criteria, only the 20 taxa found within a range of less than 13 psu might be considered reasonable salinity indicators. However, of those 20 taxa, only 4 (Haslea crucigera (W.Smith) Simonsen, Navicula normaloides Cholnoky, Navicula sp01 and Opephora horstiana Witkowski) had a \%CV of 10 or less. None of these 4 taxa were found in Lake St. Lucia.

The Shannon Diversity Indices for the diatom flora in each of the estuary sites were calculated, as well as the significant differences between the subtidal and intertidal sites. The results are shown in Table 7.

On all of the 6 occasions that the CT (Olifants and Great Berg) estuary sites were sampled, 66 taxa were identified from the 3 Olifants sampling sessions and 39 from the 3 Great Berg sampling sessions. Of these, 17 were shared. Hence, of the 105 taxa found in both estuaries, $62 \%$ were found in the Olifants Estuary, which therefore has a much more diverse diatom flora than does the Great Berg Estuary (38\%). The QS for these two estuaries was 0.17 .

In CT (82 taxa) and WT (237 taxa) estuaries, 47 taxa were found to be common, giving a QS of 0.29. The similarity between WT (237 taxa) and ST (97 taxa) estuaries, which have 81 common taxa, gives a QS of 0.48. Lake St. Lucia and estuary (96 taxa) and the ST (97 taxa) estuaries shared 24 taxa giving a QS of 0.25 . These data show that, while different taxa co-exist across different temperature regions, some taxa appear to be specific to an area.

The Great Berg Estuary had 28 dominant taxa in the 2000 survey, 21 in the 2002 survey and 18 in the 2006 survey. However, only 5 were common to all 3 surveys, which gives a 


\begin{tabular}{|c|c|c|c|c|c|c|}
\hline \multicolumn{7}{|c|}{$\begin{array}{c}\text { Table } 7 \\
\text { Shannon-Weiner Diversity indices for all the estuary and river sites and the significant difference (if any) between } \\
\text { intertidal and subtidal sites in the same estuary. }\end{array}$} \\
\hline Estuary & $\begin{array}{c}\text { Average Shannon } \\
\text { Diversity Index }\end{array}$ & $\begin{array}{c}\text { Subtidal } \\
\text { Diversity Index }\end{array}$ & $\begin{array}{c}\text { Intertidal } \\
\text { Diversity Index }\end{array}$ & $\begin{array}{c}\text { River } \\
\text { Diversity Index }\end{array}$ & $\begin{array}{l}\text { Significance } \\
\text { (Subtidal vs. } \\
\text { Intertidal) }\end{array}$ & $\begin{array}{l}\text { Average spp. } \\
\text { richness }\end{array}$ \\
\hline Great Berg & 3.5851 & 2.8912 & 4.2790 & - & NS & 39 \\
\hline Breede2 & 3.1268 & 3.2062 & 3.0473 & - & NS & 22 \\
\hline Breede3 & 4.3047 & 4.3569 & 4.2524 & 3.2958 & NS & 40 \\
\hline Bushmans & 4.0826 & 4.1638 & 4.0014 & - & NS & 61 \\
\hline Durban Bay & 2.6723 & 2.5311 & 2.8136 & - & NS & 31 \\
\hline Goukamma & 2.6421 & 2.1374 & 3.1469 & 1.6369 & NS & 20 \\
\hline Great Brak & 3.2911 & 3.4527 & 3.0757 & - & NS & 18 \\
\hline Great Fish & 3.6861 & 3.2021 & 4.4943 & - & NS & 23 \\
\hline Keurbooms & 3.2928 & 3.3984 & 3.1873 & - & NS & 32 \\
\hline Olifants & 2.6596 & 2.3545 & 2.9647 & 3.5367 & NS & 18 \\
\hline Sundays & 3.4409 & 4.1007 & 3.0097 & 1.9189 & NS & 29 \\
\hline Swartkops & 3.9309 & 3.9694 & 3.7358 & - & NS & 50 \\
\hline Mngazi & 3.2022 & 2.6751 & 3.7293 & 3.7621 & NS & 30 \\
\hline Mngazana & 3.4665 & 2.8612 & 4.0719 & 3.1529 & NS & 41 \\
\hline Mzimkulu & 2.5326 & 2.5208 & 2.5421 & - & NS & 36 \\
\hline Mlalazi & 3.9154 & 3.8380 & 3.9928 & - & NS & 29 \\
\hline Zinkwazi & 2.9598 & 2.9048 & 3.0286 & - & NS & 24 \\
\hline Goukou & 3.6423 & 3.7920 & 3.4926 & - & NS & 33 \\
\hline Gouritz & 2.9837 & 4.0353 & 1.9321 & - & 0.0143 & 26 \\
\hline Kowie & 3.6419 & 4.1182 & 3.0465 & - & NS & 56 \\
\hline All average & 3.3530 & 3.3255 & 3.3922 & 2.8839 & - & 33 \\
\hline
\end{tabular}

NS: not significant

QS of 0.15 . The Olifants survey in 2001 produced 22 dominant taxa, 19 in March 2004 and 43 in August 2004. Of these only 2 were present on all 3 occasions, i.e. QS of 0.05 . These data indicate that the species do not remain in an estuary for long periods, at least not at the same levels of abundance.

Of the 333 taxa identified in the study, 25 were found exclusively in the 2 cool temperate estuaries, 124 exclusively in the 16 warm temperate estuaries and only 7 exclusively in the 7 subtropical estuaries. Normalising these data on a per site basis gives a diatom taxa per site ratio for Cool:Warm:Sub-T of 0.41:0.78:0.1, suggesting that there is greater variability in warm temperate areas than in either of the others. In both CT and WT estuaries there were 45 species that co-occurred while 80 co-occurred in both WT and ST estuaries. The comparison on a site basis is CT:WT 0.20 and WT:ST 0.34 indicating a greater similarity between WT and ST estuary species than between $\mathrm{CT}$ and WT estuaries.

The species that occurred most frequently across all sites were Amphora coffeaeformis and Navicula gregaria. They were found in all subtidal and intertidal sites from the head to the mouth of estuaries. They were also found at cool temperate, warm temperate and subtropical sites including St. Lucia.

In order to show whether the similarities between the species in adjacent estuaries was a function of the physical distance between them, the values of Sorenson's Similarity Index (QS) between estuaries were plotted against the direct distance between adjacent estuaries. Figure 1 shows that separation distance does not correlate strongly with the QS values. As expected, the QS values for the data where the ubiquitous species had been removed from the data set were slightly lower than that where the ubiquitous species had not been removed.
The data in Fig. 1 indicate that the further away the estuaries are from each other the higher the QS value. A result of this nature is difficult to explain until the individual QS values are compared. This comparison showed that the cause was a high QS value between both the Olifants and the Great Berg estuaries and between the Great Berg and the Breede estuaries ( 0.56 and 0.55 , respectively). These are the highest values for any of the other estuary comparisons (data not shown). When these three estuaries were removed from the dataset the greater the distance between estuaries in the WT area the lower the QS value (Fig. 2).

The data in Fig. 2 indicate that estuaries with a large distance between them tend to have less similarity in their diatom species complex. The different results between Figs. 2 and 3 indicate that the species in the Olifants, Great Berg and Breede estuaries are relatively similar (QS 0.55 and 0.56 ), more similar than any of the other estuaries along the south and east coast (mean QS=0.14). These three estuaries having the highest QS values are all at the end of strong-flowing rivers lying furthest west along the coast, each with a large mean annual runoff (Olifants $1008 \times 10^{6} \mathrm{~m}^{3}$; Great Berg $913 \times 10^{6} \mathrm{~m}^{3}$; Breede 1 $873 \times 10^{6} \mathrm{~m}^{3}$ ) DEAT, 1999). From the foregoing data it seems that the Breede Estuary epipelon fit better when included with the Cool Temperate estuaries than with the Warm Temperate estuaries.

\section{Discussion}

The data reported here were collected over a few years. The reason for this was that most of the early collections were undertaken using a research grant from the Water Research 


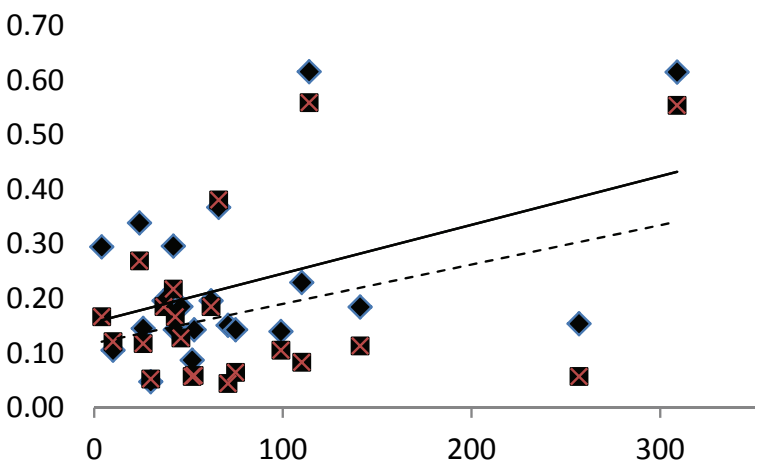

Direct distance between estuaries $(\mathrm{km})$

Figure 1

Sorenson's Similarity Index as a function of the physical distance between 2 adjacent estuaries. (Diamonds and solid line: QS with the 14 ubiquitous species included; Squares and dotted line: QS with the 14 ubiquitous species excluded).

Commission, whereas later collections took place on field trips under contract to the Department of Water Affairs during the Resource Directed Measures programme. Where a significant time period elapsed between consecutive sampling exercises, e.g. Olifants Estuary (1998, 2001 and 2004) and Great Berg Estuary (2000, 2002 and 2005) there were changes in the epipelic diatom species dominance. This indicates that, even in a permanently open estuary with a flow strong enough to maintain an open mouth, species abundance is not constant.

The number of diatom taxa found in this study (333) is similar to the 350 taxa estimated to be the total number of diatoms in the rivers of South Africa (Bate et al., 2004). Bate and Smailes (2008) found 96 taxa in St. Lucia compared to the 57 described by Cholnoky (1968). In Bate and Smailes' (2008) study the sites were sampled on 5 separate occasions at 4-monthly intervals, which would have provided additional opportunities to discover more species. The time period of Cholnoky's sampling strategy is unknown but is unlikely to have been as extended as that of Bate and Smailes (2008).

Not all of the total of 333 diatom taxa identified from the 27 estuaries (Table 2) could be identified with certainty. There were 90 that could not be satisfactorily identified to species or variety. This is a larger than desirable number, but, rather than make assumptions, names were allocated so that the degree of uncertainty was clear. Each computer image was stored on a database and was used for comparison on each occasion that a similar specimen was found. In this way consistency in identification was achieved.

Both POE and TOCE estuaries depend on the mixture of both freshwater and seawater. POEs normally have a continual supply of freshwater flowing in at the head while TOCEs frequently have the supply cut off for some time each year. In the latter case, despite closure as a result of sediment accumulation in the mouth, there often remains a supply of freshwater flowing in at the head to retain some small salinity gradient. POEs, being much larger systems, nearly always have some salinity gradient because there is a constant inflow which, when added to the tidal ebb-flow, is able to keep sediment from closing the mouth. Hence, salinity should be a suitable metric that might enable managers to gauge the extent of freshwater inflow to different systems. In this regard, diatoms which are thought to be good indicators of salinity might be a satisfactory surrogate, in that they should integrate the salinity conditions over time.

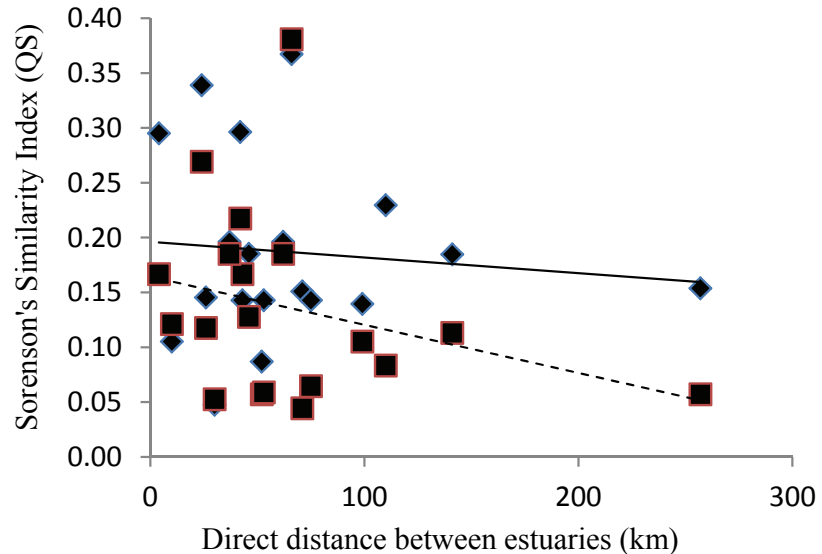

Figure 2

Sorenson's Similarity Index as a function of the physical distance between 2 adjacent estuaries. (Diamonds and solid line: QS with the 14 ubiquitous species included; Squares and dotted line QS with 14 ubiquitous species excluded).

This should result in a gradient of diatom species, from the more brack/freshwater species at the head to the more marine tolerant taxa at the mouth. The results of this study do not show such a gradient, which is contrary to the finding of McIntire (1978).

Bate and Smailes (2008) investigated diatoms in St. Lucia estuarine lake during a severe drought, when the evaporation of water had resulted in a considerable rise in salinity, from an average of below 10 psu to values as high as $155 \mathrm{psu}$. A comparison of survival of some taxa found both in St. Lucia and the other estuaries $(\mathrm{CT}-\mathrm{ST})$ showed these taxa to have a remarkable salinity range under which they are abundant. Cocconeis placentula var. euglypta (Her.). Grun was present at 1 and 56 psu. Entomoneis alata Ehrenberg was found at 20-66 psu; Fallacia sp. 01 Stickle and Mann at 7-56 psu; Gyrosigma scalproides (Rabenhorst) Cleve at 0-92 psu; Navicula abscondita Hustedt at 1-138 psu; N. dehissa Giffen at 10-56 psu; N. salinicola Hustedt at 0-133 psu; Nitzschia aremonica Archibald at 33-152 psu; N. hustedtiana Salah at 16-133 psu and Rhopalodia gibberula (Ehrenberg) O. Meuller at 34-133 psu.

The data in Table 3 show the salinity and the total number of diatom taxa found at each estuary site, both subtidal and intertidal. In the case of the Olifants Estuary (POE) intertidal Site 1 (OlI1) the salinity was 24 psu and 31 individual taxa were recognised. There was a salinity gradient ( $23 \mathrm{psu}$ ) from the mouth to the head and although there were different numbers of taxa in the sub- and intertidal areas the difference between them was not significant $(p=0.08)$. The salinity gradient in the intertidal sites was similar to those of the subtidal sites (15 psu). In the Keurbooms Estuary (POE) there was also an axial salinity gradient of about $30 \mathrm{psu}$ in both the sub- and intertidal areas. In the intertidal areas there was an average of 29 taxa with an average of 35 in the subtidal area. The difference, however, was also not significant $(p=0.59)$. In the closed Zinkwazi Estuary (TOCE) there was no salinity gradient (average $13.6 \mathrm{psu}$ in both sub- and intertidal sites) but there were a greater number of taxa in the subtidal sites, 17 vs. 31 $(p=0.01)$. In the open Mlalazi Estuary under conditions of very low inflow there was a reverse salinity gradient between the mouth and head, but there was no difference in the taxa count between sub- and intertidal sites. In order to account for these differences it is necessary to consider that intertidal 
sites have less water above them than do the subtidal sites. It is possible that under some circumstances, i.e., very calm conditions, diatoms may accumulate in the deeper areas and so exhibit a greater number of taxa. Epipelic diatoms in St. Lucia were shown to be greatly influenced by water flow (Bate and Smailes, 2008) with the same epipelon species appearing in both the water column, in response to wind-driven water circulation, and in the epiphyton. From these data, it appears that there is a considerable amount of variability in the distribution of both water quality and the numbers of diatom taxa in estuaries, to the extent that relatively few are likely to be useful as a metric in the assessment of salinity in South African estuaries.

The data collected during these surveys show that salinity tolerance in some species varied between freshwater and hypersaline, which implies that they are not restricted by virtue of the range of salinity encountered. Although the average salinity values measured in the different estuaries were lower at the head than at the mouth, the range in the different sites did not generally show a 'fresh' head. The results obtained here indicate that many species designated 'freshwater' actually show a remarkable tolerance to salinity. The result is that, at least under the conditions prevailing in South Africa, the epipelic diatoms are unlikely to be reliable salinity indicators until, perhaps, more data are collected.

Maree et al. (2000 p. 184) maintained that 'most authors accept Cape Point as the location of the boundary between the warm and cool temperate regions'. This is based on the temperature of the upwelling Benguela Current that nourishes the rich West Cape fishery. In the case of estuaries most of the research was related to ichthyofauna, many species of which interact strongly with the adjacent marine environment. There is no such described interaction in the literature with respect to the marine diatom flora. The epipelic diatom species found in the Olifants, Great Berg and Breede estuaries indicate that the latter may fit better with the cool temperate group rather than with the warm temperate group where it is currently placed.

The question is how epipelic diatoms remain distributed as a flora separate from both the marine and riverine floras. In the case of estuaries where periodic floods cause them to be 'reset', in the sense that sand and mud banks are flushed out to sea, vegetation is eroded from the banks with sediment, and periods of strong freshwater flow conditions prevail. Despite this, after a short period the typical estuarine diatom flora returns. This can be demonstrated by virtue of the similarity between the diatoms in estuaries that have recently been flooded and those that have been closed for months and sometimes years. It is clear that spores will remain after floods to regenerate the flora, and some of these may be a source of new populations.

Because there is a constant water flow at most times from the head to the mouth of an estuary, one might expect to see a distinct species gradient between the head and the mouth, as was described by McIntire (1978). However, there was no such evidence in this study. Proctor (1959) and Schlichting (1960) reported on the dispersal of freshwater algae by birds while Wurtrich and Matthey (1980) showed that birds, wind and aquatic insects are all diatom transport vectors. In the case of South African estuaries, where the distribution of diatom taxa is so wide, and recovery so rapid after a resetting flood, it does not seem impossible that birds might be important environmental factors in estuarine diatom ecology.

\section{Acknowledgements}

The initial estuary diatom survey starting in 1998 was undertaken with funds from the Water Research Commission, Project $814 / 1 / 02$. Subsequently, funds supplied by the Department of Water Affairs were used during the Resource Directed Measures studies on the Olifants and Great Berg estuaries. The study on the St. Lucia Estuary was funded by Marine and Coastal Management division of the South African Department of Environmental Affairs. Funds provided by the Department of Higher Education under the publications subsidy programme and distributed by the Research Department of Nelson Mandela Metropolitan University were used to augment the costs in the latter stages.

\section{References}

AADC (AUSTRALIAN ANTARCTIC DATA CENTRE) (2012) Australian Antarctic Data Centre, Biodiversity database. Australian Government Department of Sustainability, Environment, Water, Population and Communities. Australian Antarctic Division. URL: http://data.aad.gov.au/aadc/biodiversity/taxon profile.cfm?taxon id=118460 (Accessed 6 June 2012).

ABOAL M, ALVAREZ COBELAS M, CAMBRA J and ECTOR L (2003) Floristic list of non-marine diatoms (Bacillariophyceae) of Iberian Peninsula, Balearic Islands and Canary Islands. Updated taxonomy and bibliography. Diat. Monogr. 4 1-639.

ARCHIBALD REM (1983) The diatoms of the Sundays and Great Fish rivers in the Eastern Cape Province of South Africa. Bibliotheca Diamotologica. J Cramer, Vaduz, Germany. $431 \mathrm{pp}$.

BATE GC, ADAMS JB and VAN DER MOLEN JS (2002) Diatoms as Indicators of Water Quality in South African River Systems. WRC Report No. 814/1/02. Water Research Commission, Pretoria.

BATE GC, SMAILES PA and ADAMS JB (2004) Benthic diatoms in the rivers and estuaries of South Africa. WRC Report No. TT 234/04. Water Research Commission, Pretoria. 175 pp.

BATE GC and SMAILES PA (2008) The response of the diatom flora of St Lucia Lake and estuary, South Africa, to a severe drought. Afr. J. Aquat. Sci. 33 1-16.

LUBKE RA, GESS FW and BRUTON MN (eds.) (1988) A Field Guide to the Eastern Cape Coast. The Grahamstown Centre of the Wildlife Society of Southern Africa, Grahamstown. 520 pp.

CAMPBELL EE and BATE GC (1987) Factors influencing the magnitude of phytoplankton primary production in a high-energy surfzone. Est. Coast. Shelf Sci. 24 741-750.

CAMPBELL EE and BATE GC (1988a) The photosynthetic response of surf phytoplankton to temperature. Bot. Mar. 31 244-251.

CAMPBELL EE and BATE GC (1988b) The estimation of annual primary production in a high energy surf-zone. Bot. Mar 31 337-343.

CAMPBELL EE, DU PREEZ DR and BATE GC (1988) The light environment in a high energy surf-zone with high phytoplankton biomass. Bot. Mar. 31 329-335.

CHOLNOKY BJ (1955) Diatomeen aus salzhaltigen Binnengewässern der westlichen Kaap-Provinz in Südafrika. Ber. Deutsche Bot. Gesellsch. 68 11-23.

CHOLNOKY BJ (1963) Beiträge zur Kenntnis des marinen Litorals von Südafrika. Bot. Mar. 5 38-83.

CHOLNOKY BJ (1965) Preliminary report on the deposits and recent diatom flora of the St. Lucia Lagoon. Unpublished report. National Institute for Water Research, CSIR, Pretoria. File W 9/4/3/4 Typescript. $13 \mathrm{pp}$.

CHOLNOKY BJ (1968) Die Diatomeenassoziationen der Santa-LuciaLagune in Natal (Südafrika). Bot. Mar. Vol. XI Supplement 1-121. De Greuyter \& Co., Hamburg.

DAY JH (ed.) (1981) Estuarine Ecology with Particular Reference to Southern Africa. AA Balkema. Cape Town.

DE LA REY PA, TAYLOR JC, LAAS A, VAN RENSBURG L and VOSLOO A (2004) Determining the possible application value of diatoms as indicators of general water quality: a comparison with SASS 5. Water SA 30 325-332.

DEAT (DEPARTMENT OF ENVIRONMENTAL AFFAIRS AND TOURISM, SOUTH AFRICA) (1999) State of freshwater systems and resources in South Africa: \#1. Department of Environmental 
Affairs and Tourism. URL: http://www.ngo.grida.no/soesa/nsoer/ issues/water/state.htm\#meanannual (Accessed 6 November 2012).

GELL PA (1997) The development of a diatom database for inferring lake salinity, Western Victoria, Australia. Towards a quantitative approach for reconstructing past climates. Aust. J. Bot. 45 389-423.

GIFFEN MH (1963) Contributions to the diatom flora of South Africa. I. Diatoms of the estuaries of the Eastern Cape Province. Hydrobiologia 21 201-265.

GIFFEN MH (1966) Contributions to the diatom flora of South Africa. 11. Diatoms from the Hogsback region of the Amatola Mountains, Eastern Cape Province South Africa. Beihefte z. Nova Hedwegia Bd. 21 123-150.

GIFFEN MH (1970) New and interesting marine and littoral diatoms from Sea Point, near Cape Town, South Africa. Bot. Mar. 13 87-99.

GUIRY MD (2012a) Amphora holsatica Hustedt, 1925. In: Guiry MD and Guiry GM (eds.) AlgaeBase. World-wide electronic publication. National University of Ireland, Galway. URL: World Register of Marine Species at http://www.marinespecies.org/aphia. php? $\mathrm{p}=$ taxdetails\&id=163668 (Accessed 6 November 2012).

GUIRY MD (2012b) Hantzschia distinctepunctata Hustedt. In: Guiry MD and Guiry GM (eds.) AlgaeBase. World-wide electronic publication. National University of Ireland, Galway. URL: World Register of Marine Species at http://www.marinespecies.org/aphia. php? $\mathrm{p}=$ taxdetails\&id=180354 (Accessed 6 November 2012).

GUIRY MD and GUIRY GM (2012c) AlgaeBase. World-wide electronic publication. National University of Ireland, Galway. URL: http://www.algaebase.org/search/species/detail/?species id=33856 (Accessed 6 November 2012).

GUIRY MD (2012d) Nitzschia clausii Hantzsch, 1860. In: Guiry MD and Guiry GM (eds.) AlgaeBase. World-wide electronic publication. National University of Ireland, Galway. URL: World Register of Marine Species at http://www.marinespecies.org/aphia. php?p=taxdetails\&id=175381 (Accessed 6 November 2012).

HARTLEY B (1986) A checklist of the freshwater, brackish and marine diatoms of the British Isles and adjoining coastal waters. J. Mar. Biol. Ass. UK 66 531-610.

HARRISON TD, COOPER JAG and RAMM AEL (2000) Geomorphology, ichthofauna, water quality and aesthetics of South African estuaries. ENV-DC 2000-01. Department of Environmental Affairs and Tourism, Pretoria, South Africa.

HENDEY NI (1974) A revised check-list of the British marine diatoms. J. Mar. Biol. Assoc. UK 54 277-300.

HUSTEDT F (1930) Die Sueswasser-flora Mitteleuropas. (Reprint 1976). Fischer, Bremen. $466 \mathrm{pp}$

JOHN J (1983) The diatom flora of the Swan River Estuary, Western Australia. Biblioth. Phycol. 64 1-358.

KELLY MG, BENNION H, COX EJ, GOLDSMITH B, JAMIESON J, JUGGINS S, MANN DG and TELFORD RJ (2005) Common freshwater diatoms of Britain and Ireland: an interactive key. Environment Agency, Bristol. URL: River diatoms: a multiaccess key accessed at: $\underline{\text { http://craticula.ncl.ac.uk/EADiatomKey/html/ }}$ taxon13540980.html (Accessed 6 November 2012).

KOTSEDI D, ADAMS JB and SNOW GC (2012) The response of microalgal biomass and community composition to environmental factors in the Sundays Estuary. Water SA 38 177-190.

KRAMMER K and LANGE-BERTALOT H (1986) Susswasser von Mitteleuropa. Bacillariophyceae Teil 1: Naviculaceae. Gustav Fisher Verlag, New York. 439 pp.

KRAMMER K and LANGE-BERTALOT H (1986) Bacillariophyceae Vol 2.2 Teil: Bacillairiaceae, Epithemiaceae, Surirellaceae. Gustav Fisher Verlag, New York. 215 pp.

KRAMMER and LANGE-BERTALOT H (1986) Bacillariophyceae Vol 2.3 Teil: Naviculaceae. Gustav Fisher Verlag, New York. 215 pp.

LANGE-BERTALOT H and KRAMMER K (1989) Achnanthes, eine Monographie der Gattung. Cramer, Berlin. 393 pp.

MAREE RC, WHITFIELD AK and BOOTH AJ (2000) Effect of water temperature on the biogeography of South African estuarine fishes associated with the subtropical/warm temperate subtraction zone. S. Afr. J. Sci. 96 184-188.

McINTIRE CD (1978) The distribution of estuarine diatoms along environmental gradients: A canonical correlation. Est. Coast. Shelf Sci. 6 447-457.

MINNE C (2003) Diatoms as Indicators of Water quality in Estuaries. A Preliminary Investigation. Unpublished M.Sc. dissertation, Department of Botany, University of Port Elizabeth.

PATRICK R and REIMER CW (1966) The Diatoms of the United States Vol. 1. Monographs of the Academy of Natural Sciences of Philadelphia 13. 688 pp.

PATRICK R and REIMER CW (1975). The Diatoms of the United States, exclusive of Alaska and Hawaii, Vol. 2. Monographs of the Academy of Natural Sciences of Philadelphia $\mathbf{1 3}$

POTTER AT, PALMER MA and WJ HENLEY (2006) Diatom genus diversity and assemblage structure in relation to salinity at the Salt Plains National Refuge, Alfalfa County, Oklahoma. Am. Midl. Nat. 156 65-74.

PROCTOR VW (1959) Dispersal of fresh water algae by migratory birds. Science $130623-624$.

ROUND FE (1995) Personal communication, November 1995. Professor FE Round, Botany Department, University of Bristol, Tyndall Avenue, Bristol BS8 1TH, UK.

ROUND FE, CRAWFORD RM and MANN DG (1990) The Diatoms: Biology and Morphology of the Genera. Cambridge University Press, Cambridge. 747 pp.

SCHLICHTING HER (1960) The role of waterfowl in the dispersal of algae. Trans. Am. Microsc. Soc. 79 160-166.

SCHOEMAN FR and ARCHIBALD REM (1976) The diatom flora of Southern Africa. Special Report WAT 50. CSIR, Pretoria.

SIMONSEN R (1987a) Atlas and Catalogue of the Diatom Types of Friedrich Hustedt Vol. 1. Catalogue. J. Cramer, Stuttgart. 525 pp.

SIMONSEN R (1987b) Atlas and Catalogue of the Diatom Types of Friedrich Hustedt Vol. 2. Atlas Plates 1-395. J. Cramer, Stuttgart. $395 \mathrm{pp}$.

SIMONSEN R (1987c) Atlas and Catalogue of the Diatom Types of Friedrich Hustedt Vol. 3. Atlas Plates 396-773. J. Cramer, Stuttgart. $772 \mathrm{pp}$.

SIMS PA (ed.) (1996) An Atlas of British Diatoms. Biopress Ltd., Bristol. $601 \mathrm{pp}$.

SLOFF DS, McLACHLAN A and BATE GC (1984) Spatial distribution and diel periodicity of Anaulus birostratus Grunow in the surf zone of a sandy beach in Algoa Bay, South Africa. Bot. Mar. 27 $461-465$.

SNOW GC (2000) Structure and dynamics of estuarine microalgae in the Gamtoos Estuary. MSc thesis, University of Port Elizabeth. 104 pp.

SNOW GC, BATE GC and ADAMS JB (2000) The effects of a single freshwater release into the Kromme Estuary. 2: Microalgal response. Water SA 26 301-310.

SNOW G and TALJAARD S (2007) Water quality. In: Whitfield A and Bate $\mathrm{G}$ (eds.) A review of information on temporarily open/closed estuaries in the warm and cool temperate biogeographical regions of South Africa, with particular emphasis on the influence of river flow on these systems. WRC Report No. 1581/1/07. Water Research Commission, Pretoria. 42-67.

SÖRENSEN T (1948) A method of establishing groups of equal amplitude in plant sociology based on similarity of species content. Kongelige Danske Videnskabernes Selskab. Biol. Krifter. Bd V. 4 $1-34$.

TALBOT MMB and BATE GC (1986) Diel periodicities in cell characteristics of the surfzone diatom Anaulus birostratus their role in the dynamics of cell patches. Mar. Ecol. Prog. Series 32 81-89.

TALBOT MMB and BATE GC (1987) The spatial dynamics of surf diatom patches in a medium energy, cuspate beach. Bot. Mar. 30 459-465.

TALBOT MMB and BATE GC (1988) The relative quantities of live and detrital organic matter in a beach- surf ecosystem. J. Exp. Mar. Biol. Ecol. 121 255-264.

TALBOT MMB and BATE GC (1988) Distribution patterns of the surf diatom Anaulus birostratus in an exposed surfzone. Est. Coast. Shelf Sci. 26 137-153.

TALBOT MMB and BATE GC (1988) The use of false buoyancies by the surf diatom Anaulus birostratus in the formation and decay of cell patches. Est. Coast. Shelf Sci. 26 155-167. 
TALBOT MMB and BATE GC (1988) The response of surf diatom populations to environmental conditions. Changes in the extent of the planktonic fraction and surface patch activity. Bot. Mar. 31 $109-118$.

TALBOT MMB, BATE GC and CAMPBELL EE (1989) A review of the ecology of surfzone diatoms with particular reference to Anaulus australis. Oceanogr. Mar. Biol. Annu. Rev. 28 155-175.

TALBOT MMB and BATE GC (1989) Beach morphodynamics and surfzone chain populations. Exp. Mar. Biol. Ecol. 129 231-241.

TAYLOR JC, DE LA REY AP and VAN RENSBURG L (2005)

Recommendations for the collection, preparation and enumeration of diatoms from riverine habitats for water quality monitoring in South Africa. South. Afr. J. Aquat. Sci. 30 65-75.

TAYLOR JC, JANSE VAN VUUREN MS and PIETERSE AJH (2007) The application and testing of diatom-based indices in the Vaal and Wilge Rivers, South Africa. Water SA 33 51-60.

TAYLOR JC, HARDING WR, ARCHIBALD CGM and VAN RENSBURG L (2005) Diatoms as indicators of water quality in the Jukskei-Crocodile River system in 1956 and 1957, a re-analysis of diatom count data generated by BJ Cholnoky. Water $S A 31$
237-246.

TURPIE JK (2004) South African National Spatial Biodiversity Assessment 2004: Technical Report. Volume 3: Estuary Component. South African National Biodiversity Institute, Pretoria.

VAN HEURCK H (1896) A Treatise on the Diatomaceae. Translated by W.E. Baxter. William Wesley \& Son, London. 558 pp.

VAN NIEKERK (2007) 1. Hydrodynamics. In: Whitfield A and Bate G (eds.) A review of information on temporarily open/closed estuaries in the warm and cool temperate biogeographical regions of South Africa, with particular emphasis on the influence of river flow on these systems. WRC Report No. 1581/1/07. Water Research Commission, Pretoria. 5-23.

WHITFIELD AK (1992) A characterisation of southern African estuarine systems. South. Afr. J. Aquat. Sci. 12 89-103.

WUTRICH M and MATTHEY W (1980) The diatoms of the "Tourbiere du Cashot" peat bog (Swiss Jura Mountains). III. Transport of diatoms by wind, waterbirds and aquatic insects. Schweiz. Z. Hydrol. 42 269-284. 